\title{
Geoenvironmental characterisation of the King River Delta: A combined geophysical, geochemical and mineralogical approach
}

Sibele C. NASCIMENTO ${ }^{1}$, ANITA PARBHAKAR-FOX ${ }^{2}$, MATTHEW J. CRACKNELL ${ }^{1}$, Wei XUEN HENG ${ }^{1}$

${ }^{1}$ ARC Research Hub for Transforming the Mining Value Chain \& CODES, Centre for Ore Deposit and Earth Sciences, University of Tasmania (scdo@utas.edu.au, m.j.cracknell@utas.edu.au, weixuen.heng@utas.edu.au)

${ }^{2}$ University of Queensland, 40 Isles Road, Indooroopilly, QLD 4068 (a.parbhakarfox@uq.edu.au)

\section{Introduction}

The Mount Lyell Mining and Railway company discharged nearly $95 \mathrm{Mt}$ of tailings and $1.4 \mathrm{Mt}$ of slag from its copper, gold and silver production into the Queen River from 1916 to 1994 . Approximately $87.4 \mathrm{Mt}$ of tailings has accumulated at the King River Delta [1]. This research presents a geoenvironmental characterisation of the King River Delta that combines geophysical, geochemical and mineralogical data.

\section{Results and discussion}

Apparent resistivity and shear wave profiles suggest the baseline of the tailings at 3-5 $\mathrm{m}$ depth. Low resistivity values (i.e., $<2 \Omega \cdot \mathrm{m}$ ) characterise the salt water intrusion, while resistivity values between roughly 5 to $12 \Omega \cdot \mathrm{m}$, bellow $15 \mathrm{~m}$ depth, suggests bedrock boundaries.

Scanning electron microscope (SEM) analysis of sediments identifies pyrite, chalcopyrite, muscovite, quartz, chlorite, barite, and iron oxides in the tailings. Grains of liberated pyrite are detected on shallow sediments. In depth, liberated and euhedral pyrite crystals, encapsulated in quartz and chlorite were observed. Element mapping revealed these pyrite crystals as Co-bearing. Iron oxides rims and the presence of sulphate as rims and grains are indicators of tailings oxidation. Chalcopyrite grains were found associated mainly with muscovite, chlorite and quartz.

Pore water collected from delta is moslty acidic, ranging from $\mathrm{pH}$ 3.12-6.3. Chemical analysis reports high content of heavy metals, especially $\mathrm{Fe}, \mathrm{Cu}, \mathrm{Co}$ and $\mathrm{Zn}$. The delta tailings display high concentrations of $\mathrm{Fe}, \mathrm{Al}, \mathrm{Cu}$ and trace elements such as $\mathrm{Co}, \mathrm{Zn}$ and Ni. Geochemical static tests indicates that all samples were potentially acid forming. The majority of samples will form acid rapidly on exposure, classifying them with a medium risk of ARD and high risk of metal leaching.

[1] Locher, H 1997, Supervising Scientific Report 120 